\title{
A forgotten facial nerve tumour: granular cell tumour of the parotid and its implications for treatment
}

\author{
B LERUT ${ }^{1}, \mathrm{~J}_{\text {VOSBECK }}^{2}$, T E LINDER ${ }^{1}$ \\ ${ }^{1}$ Department of Otorhinolaryngology, Head and Neck Surgery, and ${ }^{2}$ Institute of Pathology, Kantonsspital Luzern, \\ Switzerland
}

\begin{abstract}
We present a rare case of a facial nerve granular cell tumour in the right parotid gland, in a 10-year-old boy. A parotid or neurogenic tumour was suspected, based on magnetic resonance imaging. Intra-operatively, strong adhesions to surrounding structures were found, and a midfacial nerve branch had to be sacrificed for complete tumour removal. Recent reports verify that granular cell tumours arise from Schwann cells of peripheral nerve branches. The rarity of this tumour within the parotid gland, its origin from peripheral nerves, its sometimes misleading imaging characteristics, and its rare presentation with facial weakness and pain all have considerable implications on the surgical strategy and pre-operative counselling. Fine needle aspiration cytology may confirm the neurogenic origin of this lesion. When resecting the tumour, the surgeon must anticipate strong adherence to the facial nerve and be prepared to graft, or sacrifice, certain branches of this nerve.
\end{abstract}

Key words: Granular Cell Tumour; Facial Nerve Neoplasms; Facial Paralysis; Parotid Neoplasms

\section{Introduction}

Granular cell tumours were first described in the literature in 1926 by Abrikossoff, who presented five cases of rhabdomyoma in the head and neck region. ${ }^{1}$ However, the first case of a granular cell tumour, occurring in the tongue of a 21-year-old man, was probably published in 1854 by Weber. ${ }^{2}$ This tumour was initially thought to derive from muscle cells, but recent immunohistological investigations have confirmed a neural origin. Since S-100 and cluster of differentiation 68 glycoprotein staining have become available, a Schwann cell derivation has been strongly suggested. $^{3-8}$ In 1983, May et al. described the first granular cell tumour of the facial nerve, located in the mastoid. ${ }^{9}$

Less than 20 cases of granular cell tumours of the parotid have previously been published, and this tumour is hardly ever mentioned in the differential diagnosis of parotid or facial nerve tumours. We present an additional case and review previous case reports, including the relation of these tumours to the facial nerve, their clinical presentation and the value of fine needle aspiration cytology (FNAC) in the pre-operative setting.

\section{Case report}

This case report was approved by the institutional review board of Kantonale Ethikkommission Luzern.

A 10-year-old boy was referred to our out-patient clinic with a two-year history of a firm, painless tumour at the anterior border of the right parotid gland. Facial nerve function was normal, and the tumour could easily be palpated as a solid mass with a smooth surface between the parotid gland and the masseter muscle.

On magnetic resonance imaging, a $16 \times 15 \times 10 \mathrm{~mm}$, neurogenic tumour was suspected. However, due to the tumour's close relationship with the masseter muscle, a rhabdomyosarcoma or low-grade parotid carcinoma could not be completely excluded (Figure 1).

Surgical removal was recommended. Antibody directed against epitopes of several cytokeratins (cytokeratins 5, 6, 8, 17, 19; "pan-cytokeratin"-marker). A face-lift incision was performed, and the tumour was located at the anterior rim of the superficial parotid gland. The peripheral facial nerve branches were identified, the parotid capsula opened, and a firm mass was dissected out from the parotid gland and the masseter muscle. The muscle fibres were tightly attached to the tumour capsule. One midfacial, small, peripheral branch of the facial nerve was dissected under the operating microscope, but disappeared into the tumour capsule and could not be preserved. The tumour was removed completely. The patient's facial function remained unchanged, even to the experienced observer.

Histological examination of the resected mass (Figure 2) revealed an unencapsulated, diffusely demarcated, epithelioid tumour, with distinct infiltration of a markedly fibrous stroma as well as of the resected striated muscle tissue. The tumour cells showed quite uniformly shaped, round to oval nuclei. No mitoses were observed. The cell borders were overall rather poorly defined, and there was abundant cytoplasm containing fine granules that appeared eosinophilic 


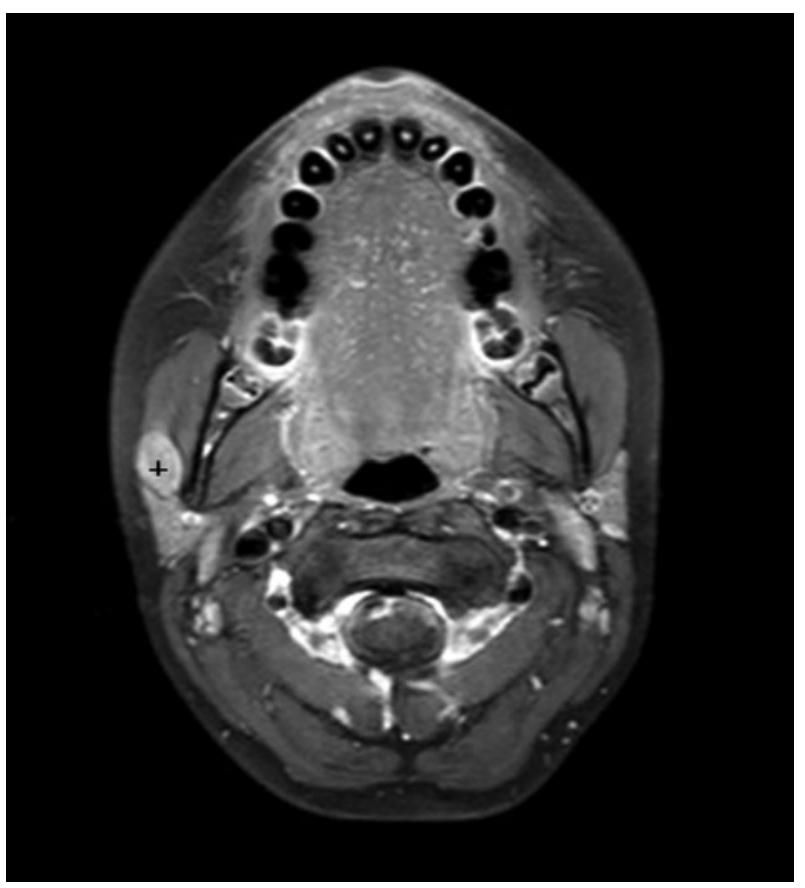

FIG. 1

Axial magnetic resonance imaging scan showing a $16 \times 15 \times 10 \mathrm{~mm}$ nodule situated between the superficial parotid lobe and the masseter muscle. T1 and T2 sequences revealed an inhomogeneous, moderately hypodense mass with homogeneous contrast enhancement $(+)$.

with standard haematoxylin and eosin staining. These granules stained positive in an additional periodic acid Schiff colouration.

Additional immunohistochemical staining revealed strong positivity of the tumour cells for S-100 and neuron-specific enolase, but complete negativity when stained for the pancytokeratin marker MNF116 antibody directed against epitopes of several cytokeratins (cytokeratins 5, 6, 8, 17, 19; "pan-cytokeratin"-marker). Staining for Ki-67 (nuclear protein associated with cellular proliferation) showed a low proliferation index of approximately 1-2 per cent.

Histological findings indicated the classic histomorphology of a granular cell tumour, confirmed by immunohistochemical analysis.

A large-calibre branch of a peripheral nerve in close proximity to the tumour could be demonstrated on serial sections. However, clear-cut transition of this nerve into the granular cell tumour was not evident.

\section{Discussion}

Since the first descriptions by Weber and Abrikosoff, many more than 1200 cases of granular cell tumour have been described, as reported by McDaniel and Apisarntarax. ${ }^{1,2,10,11}$ Granular cell tumours were originally thought to be derived from skeletal muscle cells, but nerve sheath differentiation was proposed by Feyter in 1935, and Schwann cell origin was described by Fischer and Wechsler in 1962. ${ }^{1,11-13}$

Histologically, granular cell tumours represent 0.017-0.029 per cent of all surgical specimens. They are usually (70 per cent) situated in the subcutaneous layers of the skin or head and neck region, but no organ seems to be immune to their development. Of granular cell tumours identified in the head and neck, 30 per cent are located in the tongue. ${ }^{12,14,15}$ There is a clear female predominance (two:one) and a greater prevalence in Afro-Americans than Caucasians. ${ }^{6,8,10-12,14-16}$ In 8 to 16 per cent of patients, multiple lesions are present. ${ }^{6,11,14}$ The tumour is mainly found in adults; however, we present the second case of a parotid granular cell tumour presenting in a child.

Benign granular cell tumours of the parotid usually present as slow-growing masses which rarely reach more than $3 \mathrm{~cm}$ in size. Pain, discolouration of the skin and even facial paresis may sometimes accompany this lesion. Granular cell tumours may infiltrate the gland parenchyma, and a close association with peripheral facial nerve fibres is often noted. Often, a malignant lesion of the parotid is suspected based on imaging and a clinical presentation of facial paresis or pain. Therefore, FNAC should be included in the diagnostic assessment of any parotid lesion. This investigation can help to differentiate between benign and malignant lesions, and to counter the initial suspicion of a malignant lesion (based on imaging). On reviewing the literature (Table I), of the 17 cases of parotid gland granular cell tumour previously described, a malignant diagnosis could often not be excluded. Fine needle aspiration cytology was performed in only five of the total 18 reported cases; this showed the benign origin of the lesion in all five cases. Facial nerve involvement was clearly present in six cases upon surgery, but only one patient showed pre-operative facial palsy. In most of these six cases, peripheral branches had to be sacrificed, and in the patient with pre-operative palsy a cable graft was even necessary due to the large extension of the lesion in relation to the facial nerve. ${ }^{6,7,10-12,14,17-26}$

Although malignant forms of granular cell tumours are described, they seem to be extremely rare: of all reported granular cell tumours, less than $2-3$ per cent were malignant. $^{6,10,11}$ A malignant variant must be suspected in a patient with a clinical history of rapid tumour growth, tumour size over $3 \mathrm{~cm}$ and metastasis (as reported in one case), together with suspicious histological features such as mitotic figures, cellular and nuclear pleomorphism, necrosis, and a high Ki-67 proliferation index. ${ }^{3}$ Malignant forms are usually found on the extremities and have a high mortality rate, with 40-60 per cent survival rate over three years. $6,11,12,21,27$

- Granular cell tumours are of Schwann cell origin

- Although more frequently found within the tongue, they may also arise along facial nerve branches within the parotid gland

- Fine needle aspiration of the firm mass has a high probability of leading to the correct diagnosis

Since the introduction of immunohistochemical staining, the histogenetic link between Schwann cells and granular cell tumours has been clearly demonstrated, based on additionally observed ultrastructural features and positive reactions for neural markers such as S-100 calcium-binding protein present in various tissues protein, PGP 9.5, Member of ubiquitine hydrolase protein family, present in neural tissues, but also detected in various mesenchymal tissues a-inhibin, and histocytic markers such as cluster of differentiation 68 glycoprotein (also known as KP-1 (CD68, also 
(a)

(b)
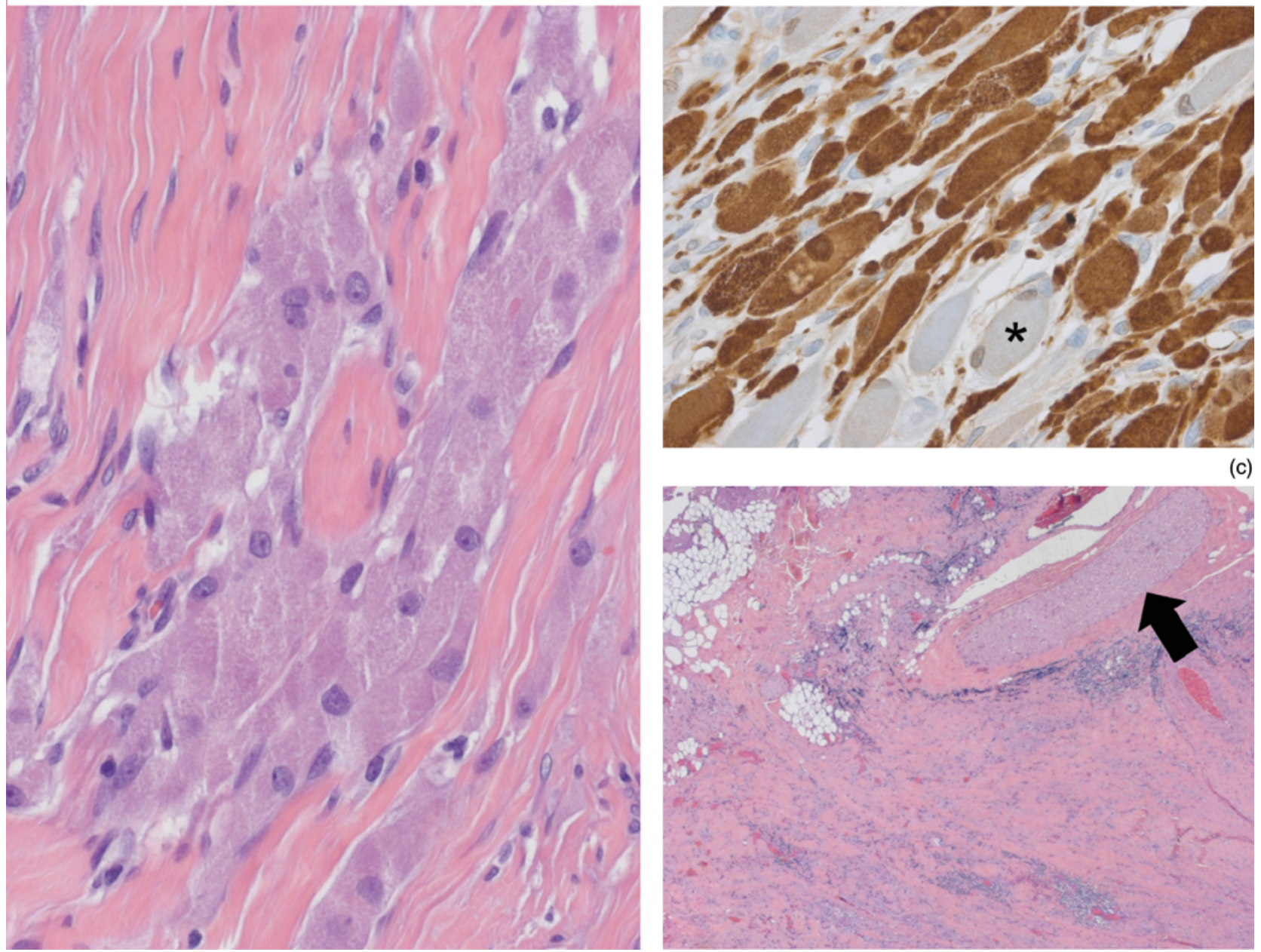

(c)

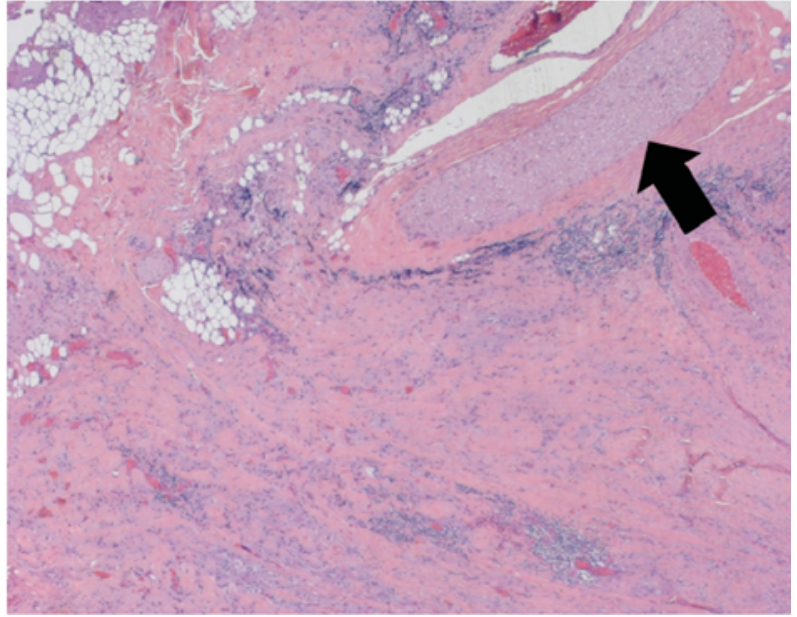

FIG. 2

(a) Photomicrograph showing cells of a granular cell tumour infiltrating fibrous stroma $(H \& E ; \times 200)$. (b) Photomicrograph showing granular cell tumour cells staining positively for S-100 $(\times 200)$; adjacent, S-100-negative striated muscle cells (asterisk) serve as an internal negative control. (c) Photomicrograph of tumour periphery showing infiltration of surrounding fibrous and fatty tissue, together with an adjacent branch of a large calibre nerve (arrow) (H\&E; $\times 25)$.

known as KP-1) KP-1: Synonym of CD68, a transmembrane lysosome associated protein located in macrophages and other cells of the macrophage/monocyte-lineage) and vimentin. ${ }^{4,5,12,24}$ It is important to realise that granular cell tumours, although of Schwann cell origin, are not histologically identical to schwannomas, but rather constitute an entity of their own. Classically, schwannomas are encapsulated tumours of spindle-shaped cells that are typically arranged in a biphasic pattern composed of hypocellular Antoni B areas and cellular Antoni A areas containing Verocay bodies and showing pronounced nuclear palisading. In contrast, granular cell tumours are usually non-encapsulated and show more epithelioid than spindle cell morphology. Both entities stain positive for S-100, but schwannomas sometimes express glial fibrillary acidic protein, which can be helpful in distinguishing the two during immunocytochemical analysis of FNAC specimens. ${ }^{28}$

In keeping with the known derivation of granular cell tumours from Schwann cells, these tumours can originate from any peripheral nerve sheath, and tight adherence to facial nerve branches is not uncommon. In at least six of the 18 reported cases of parotid granular cell tumour, such interference with the facial nerve was described. Therefore, granular cell tumours of the parotid can be facial nerve tumours. ${ }^{9,19-23}$ In the diagnostic investigation of a firm parotid lesion, one must realise that a granular cell tumour may be found within the parotid along facial nerve branches. Fine needle aspiration cytology can differentiate a neurogenic tumour from other tumours of the parotid and thus guide the surgeon. If a neurogenic lesion is found, FNAC can also differentiate a schwannoma from a granular cell tumour, with the help of immunocytochemical analysis. $^{4,5,12,24,28}$

Various decision-making algorithms have been described for the treatment of facial nerve schwannoma. In general, a 'watch and wait' attitude is adopted if there are no signs of facial palsy. ${ }^{29}$ However, in the case of granular cell tumour, resection is advised due to this tumour's tendency to grow and minor risk of malignancy. Treatment must be discussed with the patient, including the risk that, if strong adherence to the facial nerve is found, small peripheral branches may need to be sacrificed. The patient should also be aware that, in the case of larger facial nerve involvement, grafting may be required, with (temporary) palsy as a consequence. Tumour origin from other nerves within the parotid (secretory or sensory) can only be verified at surgery.

At surgery, the lesion is usually apparent as a hard, yellowish nodule in a distal region of the parotid gland..$^{6,7,10,11}$ Total 


\begin{tabular}{|c|c|c|c|c|c|c|c|c|c|}
\hline \multicolumn{10}{|c|}{$\begin{array}{c}\text { TABLE I } \\
\text { ND GRANULAR CELL T }\end{array}$} \\
\hline Study & Age (y) & Sex & Complaint & Imaging & FNAC & $\begin{array}{l}\text { Size } \\
(\mathrm{cm})\end{array}$ & Site & Surgery & VII involved? \\
\hline de Sequeira et al. ${ }^{17}$ & 31 & $\mathrm{~F}$ & Mass & None & None & 0.7 & Multiple & Node picking & No \\
\hline Nussbaum \& Haselkorn ${ }^{18}$ & 36 & M & Mass & None & None & 2.5 & Single & Hockeystick & No \\
\hline Seifert et al. ${ }^{19}$ & 6 & $\mathrm{~F}$ & Mass & None & None & 2.0 & Single & NS & Yes \\
\hline Nielsen et al. ${ }^{20}$ & 51 & $\mathrm{~F}$ & Mass & None & Benign & 1.5 & Single & Total parotidectomy & Yes \\
\hline Lack et al. ${ }^{14}$ & NS & NS & NS & NS & NS & 1.0 & Single & NS & NS \\
\hline Apisarnthanarax ${ }^{11}$ & 52 & $\mathrm{~F}$ & Mass & NS & NS & 1.5 & Single & NS & NS \\
\hline Mullins \& Wagner ${ }^{3}$ & 60 & $\mathrm{~F}$ & Mass & None & None & NS & Metastasis & NS & No \\
\hline McDaniel $^{10}$, case 1 & NS & NS & NS & NS & NS & NS & Single & NS & NS \\
\hline McDaniel $^{10}$, case 2 & NS & NS & NS & NS & NS & NS & Single & NS & NS \\
\hline Curtis et al. ${ }^{6}$ & 37 & $\mathrm{~F}$ & Mass & MRI & Benign & 2.0 & Multiple & Sup parotidectomy & NS \\
\hline Carinci et al. $^{21}$ & 30 & $\mathrm{~F}$ & Mass, pain & $\mathrm{CT}$ & Benign & 2.0 & Single & Parotidectomy & Yes \\
\hline Said Al Naief et al. ${ }^{22}$ & 49 & $\mathrm{~F}$ & VII palsy, pain & CT, MRI & None & 3.0 & Single & Sup parotidectomy & Yes, cable graft \\
\hline Smith et al. & 48 & $\mathrm{~F}$ & Mass & MRI & None & 1.5 & Single & Total parotidectomy & Temp palsy post-op \\
\hline Chae et al. ${ }^{24}$ & 46 & $\mathrm{~F}$ & Mass & CT & Benign & 1.0 & Single & Sup parotidectomy & NS \\
\hline Bonfils et l. $^{7}$ & 55 & $\mathrm{~F}$ & Mass & MRI & Benign* & 3.0 & Single & Enucleation & No \\
\hline Dismosthenous et al. ${ }^{25}$ & 47 & $\mathrm{~F}$ & Mass & NS & None & 3.0 & Single & NS & NS \\
\hline Bomfin et ll. $^{26}$ & 58 & $\mathrm{~F}$ & Mass & NS & None & 3.0 & Multiple & Sup parotidectomy & NS \\
\hline Present & & M & Mass & MRI & None & 1.6 & Single & Sup parotidectomy & Yes \\
\hline Total $^{\dagger}$ & Mean 41 & $13 \mathrm{~F} 2 \mathrm{M}$ & 15 mass 2 pain 1 VII palsy & 5 MRI 3 CT & 5 of 18 All benign & Mean 1.95 & 14 single 3 multiple & & 6 of 18 \\
\hline
\end{tabular}

${ }^{*}$ Schwannoma. ${ }^{\dagger} 18$ cases. $\mathrm{Y}=$ years; $\mathrm{FNAC}=$ fine needle aspiration cytology; $\mathrm{VII}=$ facial nerve; $\mathrm{F}=$ female; $\mathrm{M}=$ male; $\mathrm{NS}=$ not stated; $\mathrm{MRI}=$ magnetic resonance imaging; sup $=$ superficial; $\mathrm{CT}=$ computed tomography; post-op = post-operatively 
removal with margins is advised as recurrence is found in $5-15$ per cent, probably due to incomplete removal. ${ }^{10,14,16}$ Radiotherapy and chemotherapy appear to be of no value for granular cell tumour treatment, in the peri-operative setting. $6,7,10,11,14,17-26$

\section{Conclusion}

Current textbooks do not mention granular cell tumour within the differential diagnosis of parotid lesions or facial nerve tumours. Even though parotid granular cell tumours are benign lesions, they often mimic facial nerve tumours and thus must be treated accordingly. The patient must be informed of the higher risk of post-operative facial palsy, compared with 'normal' parotid surgery for other benign lesions. Pathologists must be aware of this lesion, and should confirm their identification using appropriate immunohistochemical staining. The surgeon should be aware that even a benign lesion can present with facial weakness, pain and skin discolouration. Fine needle aspiration cytology will assist decision-making and patient counselling. The surgeon should also anticipate strong adherence to the facial nerve and surrounding tissue during superficial parotidectomy, and should be ready to sacrifice and graft any peripheral branch of the facial nerve if necessary.

\section{Acknowledgement}

The authors acknowledge the support of the Fisch International Microsurgery Foundation (see www.fimf.ch) for providing a three-month neuro-otology fellowship for Dr Lerut at the Department of Otorhinolaryngology in Luzern.

\section{References}

1 Abrikossoff A. About myoms originating from the striated voluntary innervated musculature. Virchows Arch A Pathol Anat 1926;260:215-33

2 Weber CO. Anatomical examination of a hypertrophied tongue and special considerations on tumours of the striated muscle fibres. Virchows Arch A Pathol Anat 1854;7:115-25

3 Mullins GM, Wagner JW. Multiple granular cell myoblastomas - a case report. Ir Med $J$ 1984;9:286-7

4 Kurtin PJ, Bonin DM. Immunohistochemical demonstration of the lysosome-associated glycoprotein CD KP-1 in granular cell tumors and schwannomas. Human Pathol 1994;2511:1172-8

5 Le BH, Boyer PJ, Lewis JE, Kapadia SB. Granular cell tumor: immunohistochemical assessment of inhibin-alpha, protein gene product $9.5, \mathrm{~S} 100$ protein, CD68, and $\mathrm{Ki}-67$ proliferative index with clinical correlation. Arch Pathol Lab Med 2004; 128:771-5

6 Curtis BV, Calcaterra TC, Coulson WF. Multiple granular cell tumor: a case report and review of the literature. Head Neck 1997; 19:634-7

7 Bonfils P, de Preobrajenski N, Elouaret Y, Badoual C, Halimi P, Bigorgne C. Granular cell tumours Abrikosoff's tumour of the parotid region [in French]. Rev Laryngol Otol Rhinol (Bord) 2006;127:183-5

8 Regezi JA, Batsakis JG, Courtney RM. Granular cell tumors of the head and neck. J Oral Surg 1979;37:402-6

9 May M, Beckford NS, Bedetti CD. Granular cell tumor of facial nerve diagnosed at surgery for idiopathic facial nerve paralysis. Otolaryngol Head Neck Surg 1985;931:122-6

10 McDaniel RK. Benign mesenchymal neoplasms. In: GL Ellis, PL Auclair, DR Gnepp, eds. Surgical Pathology of the Salivary Glands. Washington DC: Saunders, 1991;489-513
11 Apisarnthanarax P. Granular cell tumour: an analysis of 16 cases and review of the literature. J Am Acad Dermatol 1981;5: $171-82$

12 Argenyl ZB. Granular cell tumour. In: LeBoit PE, Burg G, Weedon D, Sarasin A, eds. World Health Organization Classification of Tumours: Pathology and Genetics Skin Tumours. Lyon: IARC, 2006;274-5

13 Fisher ER, Wechsler H. Granular cell myoblastoma: a misnomer: electron microscopic and histochemical evidence concerning its Schwann cell derivation and nature. Cancer 1962;15: 936-54

14 Lack EE, Worsham GF, Callihan MD, Crawford BE, Klappenbach S, Rowden G et al. Granular cell tumor: a clinicopathologic study of 110 patients. J Surg Oncol 1980;13:301-16

15 Batsakis JG, Manning JT. Soft tissue tumors: unusual forms. Otolaryngol Clin North Am 1986;194:659-83

16 Frable MA, Fischer RA. Granular cell myoblastomas. Laryngoscope 1976;86:36-41

17 de Sequeira OF, Marcos-Martins O, Hercules HC. Multiple myoblastoma with bronchial, lingual and parotid locations [in Portugese]. Hospital Rio J 1970;77:1179-95

18 Nussbaum M, Haselkorn A. Granular-cell myoblastoma in parotid gland. N Y State J Med 1972;72:2887-8

19 Seifert G, Heckmayr M, Donath K. Granular cell tumour of the parotid gland. The differential diagnostic criteria [in German]. Laryngol Rhinol Otol Stuttg 1977;568:695-703

20 Nielsen M, Thomsen J, Albrechtsen R, Bak-Pedersen K. Granular cell myoblastoma in the parotid gland. J Laryngol Otol 1979;93:943-8

21 Carinci F, Marzola A, Hassanipour A. Granular cell tumor of the parotid gland. Int J Oral Maxillofac Surg 1999;28:383-4

22 Said Al Naief N, Ivanov K, Jones M, Som P, Urken M, Brandwein M. Granular cell tumor of the parotid. Ann Diagn Pathol 1999;3:35-8

23 Smith JL 2nd, Feehery JM, Ohara BJ, Rao VM, Vernose GV. Granular cell tumor of the parotid: a case report and literature review. Ear Nose Throat J 2001;80:454-7

24 Chae SW, Sohn JH, Shin HS. Granular cell tumor of the parotid gland: a case report. Acta Cytol 2002;46:550-4

25 Dimosthenous K, Righi A. Granular cell tumor of the parotid gland: an exceptionally rare occurrence. Int J Surg Pathol 2008; 16:213-14

26 Bomfin LE, Alves F de A, de Almeida OP, Kowalski LP, Perez DE. Multiple granular cell tumors of the tongue and parotid gland. Oral Surg Oral Med Oral Pathol Oral Radiol Endod 2009;1075: $10-13$

27 Fanburg-Smith JC, Meis-Kindblom JM, Fante R, Kindblom LG. Malignant granular cell tumor of soft tissue: diagnostic criteria and clinicopathologic correlation. Am J Surg Pathol 1998;22: 779-94

28 Ordóñez NG, Mackay B. Granular cell tumor: a review of the pathology and histogenesis. Ultrastruct Pathol 1999;234: 207-22

29 Alicandri-Ciufelli M, Marchioni D, Mattioli F, Trani M, Presutti L. Critical literature review on the management of intraparotid facial nerve schwannoma and proposed decision-making algorithm. Eur Arch Otorhinolaryngol 2009;2664:475-9

Address for correspondence:

Prof Dr Thomas E Linder,

Chairman, Dept of Otorhinolaryngology, Head \& Neck Surgery,

Kantonsspital Luzern,

Spitalstrasse, 6000 Luzern, Switzerland

Fax: 0041412054995

E-mail: thomas.linder@ksl.ch

Professor T E Linder was the 2010 Journal of Laryngology \&

Otology Visiting Professor for Otology.

Professor T E Linder takes responsibility for the

integrity of the content of the paper

Competing interests: None declared 